\title{
LIFELONG EDUCATION BETWEEN THE USEFUL AND THE USELESS: LEARNING CITY TOPONYMY
}

\author{
Livio Clemente Piccinini \\ Mario Taverna \\ Giovanni Tubaro \\ Udine University, Italy
}

\begin{abstract}
The aim of the paper is to discuss the balance between the useful and the useless in the actual lifelong learning, in a conceptual scheme that goes beyond purely economical or technical evaluations. The authors chose an exemplary field starting from last year's paper on the exploration of nets. In order to delimitate the research field, the official city toponymy has been considered, both in the structure of hypernyms and in the choices of proper names. The analysis considers Italian city hypernyms, with some regional or local varieties, explaining the underlying historical and contact phenomena. The grouping of similar proper names is then analyzed, finding out segmentations and some strange aversions. The non correspondence between the conceptual hierarchy and the perceptual geographical hierarchy is highlighted. Useful practical reference systems are compared with official ones.
\end{abstract}

Keywords: city toponimy, geographical hypernyms, landmark systems, network representation, useful vs useless

\section{Introduction}

It is not true - even in times of crisis - that it is only useful to make a profit. There is, in mercantile democracies, knowledge which is deemed to be "useless" that instead proves to be of an extraordinary utility. We must remember the noted essay by Nuccio Ordine (Ordine 2013) focused on the usefulness of the useless and the uselessness of profit. Through the reflections of great philosophers and of great writers, Ordine shows how the obsession with ownership and the cult of usefulness ends up sapping the spirit, putting in danger not only schools and universities, art and creativity, but also some fundamental values such as human dignity, love, and truth.

Abraham Flexner - in his essay added to the Italian edition - recalls that even the sciences teach us about the usefulness of the useless. Eliminating the gratuitous and unnecessary, killing those luxuries deemed to be superfluous, homo sapiens can hardly make humanity more human. These conclusions may appear onesided as the testimonies come from thinkers and artists, but Flexner, with the intuition of the Centre for Advanced Studies in Princeton, should be above all suspicion. We add the synthesis position held by Herbert Simon, Nobel laureate in economics and a great protagonist of the foundations of artificial intelligence, who never wanted to separate economic and technological components from human knowledge, behaviour and psychology (compare Simon 1991).

Going down to real life we find that the useful and the useless continually collide and lead to conflicting evaluations. There may be a temptation to consider as useless what cannot be measured in monetary terms, as is often the 
case for the culture, the fundamental research and also for the health of the environment and for the landscape. With regard to the highest and most noble, such as for example charity, honesty, science, art, the more they are shared the more they highlight each other, even if there is the opinion that as long as the assets are not subject to ownership and cannot be divided they lack value, as already noted by Dante (in his otherworldly dialogue with Virgil)

"How can each one of many who divide a single good have more of it, so shared, than if a few had kept it?" He replied:

"Because within the habit of mankind you set your whole interest on earthly things, the true light falls as darkness on your mind..."

[Alighieri], Purgatorio, 15, 61-66

The systems of patents, copyrights, protection of signatures, indexing of scientific articles, have reduced the arts and science to divisible assets. For the moral virtues there are indirect ways of publicising and valorise them also through the mass media and social networks, so that they too can become divisible assets and therefore descend in the much esteemed category of profit. It is necessary to understand which needs and which desires are fulfilled by the useful, and what is the threshold above which one prefers other less useful assets. Gratuitousness is at the base, whether it is of culture, of entertainment, or of psychophysical pleasure. Hobbies, collections, sports, the search for typical food and wine products, all are forms of futility perceived as a completion of one's own personality. The complete man, as Machiavelli observed about Lorenzo the Magnificent, and as Sofri observes about the same Machiavelli in his recent book (Sofri, 2013:75), must unite the "voluptuous life" and the "serious life", so as to show in himself "the existence of two different people."

\section{Street, Road, Square}

In this paper we start from last year's paper about the exploration of a city (Taverna 2013), trying to distinguish between useful and useless. Last year's paper ended with the emblematic question will smart city make more functional the use of the city? Will make it more challenging and more enjoyable? The first category represents the useful, the second category represents the useless. There are moments and circumstances when optimization and rationalization are required, and moments when leisure is needed to enjoy our lives. The knowledge of a city lies in the territorial representation and its associated toponymy. But a fundamental question was presented by Charles Dodgson (alias Lewis Carroll) in the dialog between Alice and the Cheshire Cat

"Would you tell me, please, which way I ought to go from here?"

"This depends a good deal on where you want to get to", said the Cat.

"I don't much care where - " said Alice.

"Then it doesn't matter which way you go", said the Cat. Carroll 1865, chapter 6 
The toponymy frame is conditioned by the language and also by the different regions; we shall refer to Italy. We distinguish between three general cases:

1. Linear structures

2. Rounded structures with a linear boundary

3. Complex structures (labyrinth)

The third case is typical of non structured hamlets and at present survives only in some parts of the mountains: a typical case is Sappada in Veneto, where the municipality is divided into 14 hamlets. The numbers of the houses are therefore somewhat erratic, just like it used to happen in Napoleon's cadastral system. A case of superposition of the modern system with the ancient cadastral structure is still available in the historical center of Venice, where the address of the houses requires the "Sestiere" (one of the six parts of the city), and then a number, but the geometric pattern, with identifiable streets and squares, is described on the maps and labeled on many crossings of the streets. Some problems may still arise where countryside and urban structure are totally mixed, as it happens in Italy around the Po Plane (Megalopolis structure: Gottmann 1961, for an interesting Italian regional case compare Rizzo 2013). In general the existing complex structures either are rather small (garden hamlets) or represent big public complexes like hospitals, universities, airports, military dwellings, parks, where an interior system of references holds, and exterior official localization refers only to some entrance more or less suitable, while the subsequent search must be performed according to the local rules.

We come now to the lexical analysis of the one dimensional paths in the interior of towns. In most languages there exists a hypernym that corresponds to street, In Italian there are three most common names: via, corso, viale. They correspond to the couple street, avenue. Via corresponds almost always to street, while corso mostly means a large important road in the central area of the city (its origin comes from the proper name Via del corso (=Race street) in Rome, a very long, straight and central road where horse races, corse in Italian, took place in some particular days. The name viale corresponds to a large road surrounded by trees. In some cities the name via is substituted by strada, that mostly corresponds to road and is usually reserved to main roads that lead outside of the city (but they can still be called via). Strada seems to alternate with borgo, in the sense of a hamlet lying along a single main road. The ancient word Contrada was used to cover a similar, but more interconnected, structure. As for small lanes the word vicolo (vico in Genoa) is very common. Remark that small blind alleys very often are merged in the order structure of the main road, especially when they are private.

The number of lexical variants of restricted use is more or less large in the different languages, and a classification connected with the propensity to diversification (compare Chang 2011) should be attempted. Narrow streets have many local names, especially in sea towns: we can find rua, ruga mainly along Tyrrhenian Sea, while along Adriatic Sea calle, is the most used and can be 
compared with Spanish hypernyms. An interesting specification in some cities is related to the constructive history of the road, so that salizzada in Venice means a paved route, while rio terrà, interrato, means a filled up channel.

Big roads often have topological descriptors, the most common of which is circonvallazione (circumvallation), but also in the small scale streets salita, costa (slopes upwards), scala (staircase). Hapax legomena seem to be arco, raggio (arc, ray) for the case of Lignano (a fashionable sea resort) in order to describe a spiral pattern interconnected by radial streets. As for large streets, some non-common names are stradone (at Piacenza), Foro (in Palermo and in Milan), Lista (Venice), Liston (Verona); suburban footways very often retain the name passeggiata (promenade).

A specific form of hypernym is reserved to the banks of rivers. While the sea side has the generic term lungomare (= along the sea), each river seems to have its own name according to the the river, so we get lungotevere in Rome, lungarno ) in Florence and in Pisa and so on. The lake sometimes uses a generic lungolago, and sometimes uses a specific term with the name of the lake, such as lungolario (at Como). The embankments have some general terms and many local terms: common is riva (bank), that becomes riviera in Padua, or ripa in Milan, but also rigaste in Verona. On the sea the main term is Fondamenta in Venice, and Calata in Liguria, with reference to a slope where boats can be pulled onto the beach. Finally some terms are derived from the military origin of the city walls. Examples are bastioni (in Milan), baluardi (at Novara), mura (at Faenza), spalti (at Alessandria), rampari (at Ferrara).

Fortunately when one searches for an item in the guide of the city, the list is arranged according to the proper name, with some fuzziness about the use of prepositions. Only in case of duplicate proper names attention is required to the hypernym, since the coincidence of the proper name does not guarantee physical neighborhood, just as it happens for example in Rome where Piazza Vittorio Emanuele $2^{\text {nd }}$ is two miles away from Corso Vittorio Emanuele $2^{\text {nd }}$.

Square has a good hypernym in piazza. The most common variants are piazzale, slightly contemptuous since it means "large, non-structured square". Much less used are piazzetta (small square), corte (small and enclosed, courtyard), rotonda or anello (circus). In Venice the usual name is campo, campiello (field, small field). Large squares sometimes retain the original specification of parco (park), prato (meadow), spianata (plane).

\section{Proper names of the streets}

Which is the best way of representing a point in a plane? Every learned person knows that a two-dimensional Cartesian product is suitable, hence a latitude and a longitude are enough for a very sharp representation (just what GPS does). This information becomes more palatable when it is joined with some information on the neighborhood (buildings, roads). A GPS does not give family 
language information, such as "grand mama's house", "around the grocer's shop", "where old John lived", that are nice and emotionally much more pregnant than an official address. Every town has a full set of nicknames. In some cases a nickname becomes generally known and can survive as an official name, or at least as a popular alternative name. A most striking case is Naama Bay at Sharm el Sheik, where actually, when Sinai was militarily occupied by Israel, there was the kiosk of miss Naama.

For a net of streets a simple representation is what is used in the graphs: starting point and end point, but again coordinates must be used. A friendly possibility is thus to append labels to the coordinate grid, setting a system of landmarks; this is what the non-experienced traveler usually does, memorizing some well recognizable buildings, that can be referred also to the inhabitants. The usual reference system on the map is the division in squares, that can be considered a fuzzy form of Cartesian coordinates, followed by an empirical search. The computer can perform this task with various algorithms, that allow also the search of neighbors and of crossings. Numbered streets like in New York are functional but do not have any particular personality, even if their subsequent history can convey some meaning on them, as it happens for the celebrated Fifth Avenue.

Appending a history to each street should be useless, if it does not add information to the place where the street is located. Anyhow it is easier to remember a name rather than a number, hence also a name could be useful, as it is shown by mnemonics. Furthermore the set of names of the streets of a town may convey some blurred record of the history of the town and its country.

In the last century the names of the streets have got an official state (with the exception of Venice), hence have become unambiguous and have become persistent, so that the total or partial change of name has become an official act, and thus is increasingly rare. This means that the toponymy of a city has acquired stability and evolves just like languages evolve, usually adding new words, specifying existent words (corresponds to a part of a road that gets a new name), recovering an obsolete word (an old name is added to the present name) and so on. As De Saussure taught the system can be studied in its diachrony as well as in its synchrony. When we arrive in a new city we meet its toponymy in a synchronic frame, without particular information on its past history, exactly as we learn a foreign language in synchrony.

First of all there are some syntactic rules that hold almost everywhere. For example the names of ancient crafts usually have a medieval origin, and the lanes with those names can be found in the center of the city (compare Guidoni 1989), while names of the first industrial development such as mills or cottonmills are to be found outside the center of the town, as well as military names. Some names are politically correct and can be found almost in every Italian town: the fathers of the Unity of Italy, especially Garibaldi, Cavour and Mazzini are quite common. In almost all towns and cities there is via Roma (with the 
exception of Rome itself). These "official" names are easily found in the center of the cities, since the original names have been removed, even if very often they survive in the spoken system of communication.

The study of collections of related names is interesting. When an important new addition enlarges the city it is usual to give a system of related names, so that the type of name suggests also the part of the city where it must be found. We recall some examples taken from Rome. Along via Nazionale (from the center of the city to the main Railway station) the new streets recalled the main Italian cities (Venice, Naples, Genoa, Florence, Palermo). All other Italian main towns were recalled in the city Eastern expansion (between 1880 and 1920), but they do not form a compact block and the distributions seems to be at random. On the contrary the names of all the regions form a compact block around the famous Via Veneto. Remark anyhow that the whole name of via Veneto is via Vittorio Veneto, a historical town of Veneto, not the actual region. In one case the name of the town means something else, since Prato means meadow, and there was already a via del Prato (meadow street), hence Prato has no street dedicated to the town.

A systematic toponym system was adopted in the very important borough named Prati (Northern of the river between Saint Peter and Pincio Hill). Most streets have the names of ancient Romans, famous both as politicians and poets. In a Western further expansion all the names are taken from the history of Venice Republic (colonies, admirals, battles). On the contrary there are strange hidiosyncrasies for philosophers, both modern and ancient, and for Greek classical poets, that have been recorded only in recent times in the extreme outskirts of the city. Only Homer has a dignified location near the Modern Art Gallery, together with Cervantes (!). Important names of foreign countries, foreign writers, foreign artists must be searched in the modern South Western borough named EUR (Universal Expo Rome) and in its further western outskirts between Rome and the sea.

A curious name structure has been used in Centocelle borough, in the East outskirts between Prenestina and Casilina roads, where almost all the streets and squares have names of flowers, even not common. A singular expansion followed: usually the big main roads delimit the boroughs and hence also the semantic territories. Here Togliatti Avenue forms a strict boundary, but all the same across this boundary the botanical trend was followed. The choice of toponimy at Centocelle recalls the cumbersome system of Fregene, the sophisticate sea resort of Rome, where all the names denote Italian sea resorts, even very small.

\section{Conclusions}

A more general question may arise: do toponyms change the perception of the city? Or does the contrary hold, namely a beautiful part of the city positively 
influences the memory of the street name, or does a decayed part damn the memory (compare Calvino, 1972, section "The city and the name"). In contemporary advertising techniques the psychology of the perception is widely used, and many different stimuli work together, especially pleasant rather than useful stimuli, so that aesthetical and gastronomic suggestions are strongly connected. Where this integration does not happen because of an exceeding competition between too small establishments progress in tourism lacks (Droli, 2013). Actually the most vital branches in those lines of production now attempt to approach the final consumer more directly, expanding their core business (compare Chang, 2012).

This problem is also related to the hierarchy: in the personal (and also common) knowledge system many classes of names can be recognized, classified, and ordered according to their importance. In the street toponimy the hierarchy can be completely distorted, as it happened in Rome with the streets dedicated to the main Italian cities, that are small, dark lanes near the railway station, with the only exception of Venice that is honored also by the most central square of the city, where once there was the Venetian embassy. For a suitable comparison of order structure the classical Spearman and Kendall correlation indexes are too sensitive to fuzziness, so that more robust measures must be introduced, as it was performed in Chang 2013, Section 3.1 for the hierarchical structure of economy. On the linguistic side some forms of fusion, of overlapping, of bifurcations are to be easily found, but unlike what happens in spoken languages, where new experiments are subjected to a continuous test, the official system of names becomes frozen and conservative, somewhat like the written language of nations like Italy and France. The check phase may happen only before official statements, for not important outskirt lanes, and also in this case an official system of names can be superposed. Of course the practical, empirical system of landmarks can change exactly as the spoken language: actually it is a part of the semantics of the language.

\section{References}

1. Alighieri, Dante (1957-2001). Divina Commedia translated by Ciardi, John. New York: Signet Classics.

2. Calvino, Italo (1972). Le città invisibili. Torino: Einaudi.

3. Carrol, Lewis (1865). Alice's Adventures in Wonderland. London: Macmillan.

4. Chang, T.F. Margherita; \& Iseppi, Luca (2011). Specialization versus Diversification in EU Economies: a Challenge for Agro-food? "Transition Studies Review", Volume 18, n. 1, 16-37, Springer, ISSN 1614-4007, DOI: 10.1007/s11300-011-0196-0.

5. Chang, T.F. Margherita; \& Iseppi, Luca (2012). EU Agro-Food Chain and Vertical Integration Potentiality: a Strategy for Diversification? "Transition Studies Review", Volume 19, n. 1, 107-130, Springer, ISSN 1614-4007, DOI: 10.1007/s11300-011-0196-0.

6. Chang, Ting Fa Margherita; \& Piccinini, Livio C.; \& Iseppi, Luca; \& Lepellere, M. Antonietta (2013). The Black Box of Economic Interdependencein the Process of Structural Change, Italian Journal of Pure and Applied Mathematics, 31, 285-306. 
7. Droli, Maurizio; \&, Chang, T.F. Margherita; \& Iseppi, Luca; \& Piccinini, Livio C. (2013). Managing trade contacts in HotRest intermediate markets: a resource-based view analysis in EU countries. Tourism Economics, ISSN: 1354-8166, DOI: $10.5367 /$ te.2013.0311.

8. Gottmann, Jean (1961). Megalopolis. The Urbanized Northeastern Seabord of the United States, New York: The Twentieth Century Fund Inc.

9. Guidoni, Enrico (1989). Storia dell'Urbanistica. Il Duecento. Bari: Laterza, 1-20.

10. Ordine, Nuccio (2013). De l'utilité du savoir inutil. Paris: Les belles letters.

11. Piccinini, Livio C.; \& Lepellere, M. A.; \& Chang, T.F. M. (2013). Utopias of Perfection and their Dystopias. In Society, Integration, Education, Proc. of Intern. Conference: Sabiedriba, Integracija, Izglitiba, Vol. 3, 189-200.

12. Rizzo, Marcella; \& Giudice, V.L. (2013). Structural Analysis of Forms of Local Partnership in the Val d'Anapo Area. Quality - Access to Success 14 (Suppl. 1), 188-193.

13. Schenkel, Marina; \& Chang, T.F. Margherita; \& Iseppi, Luca (2013). Utopias and Dystopias of the Metropolitan City. In Society, Integration, Education, Proc. of Intern. Conference: Sabiedriba, Integracija, Izglitiba, Vol. 5, 245-256.

14. Simon, Herbert A. (1991). Models of my Life, Harper Collins: Basic Books.

15. Sofri, Adriano (2013) Machiavelli, Tupac e la Principessa. Palermo: Sellerio.

16. Taverna, Mario; \& Piccinini, L. C.; \& Chang, T.F. M.; \& Iseppi, L. (2013). Structures and Paths for the Exploration of Landscape-Cultural Mosaic. In Society, Integration, Education, Proc. of Intern. Conference: Sabiedriba, Integracija, Izglitiba, Vol. 1, 517-527.

$\begin{array}{ll}\text { Livio Clemente Piccinini } & \text { Department of Civil Engineering and Architecture Udine } \\ & \text { University, Italy } \\ & \text { Email: livio.piccinini@uniud.it } \\ & \text { Department of Civil Engineering and Architecture Udine } \\ \text { Mario Taverna } & \text { University, Italy } \\ & \text { Email: mario.taverna@uniud.it } \\ \text { Giovanni Tubaro } & \text { Department of Civil Engineering and Architecture Udine } \\ & \text { University, Italy } \\ & \text { Email: giovanni.tubaro@uniud.it }\end{array}$

